\title{
POTENTIAL OF ORGANIC TEA PRODUCTION IN SRI LANKA AS A MEASURE OF ENVIRONMENTAL MANAGEMENT IN UP COUNTRY
}

\author{
HMAUK Herath, BMNK Dorabavilla, JMDDJ De Alwis \\ and BMS Batagoda \\ Environmental Economics and Global Affairs Division, \\ Ministry of Environment and Natural Resources, Battaramulla
}

Promotion of organic farming has been widely accepted as a panacea for emerging environmental problems such as land degradation and surface water pollution. Being an agricultural country Sri Lanka has large potential for organic industry. Tea itself contributes to $13 \%$ of export earnings in Sri Lanka. Around 180,000 ha of land is presently under tea cultivation. Conventional tea cultivation practice that use a massive amount of synthetic chemicals has raped the natural environment in the up country and is reported to have affected the health of human beings and other living organisms. Considering these adverse effects organic tea cultivation has been introduced which uses zero level of inorganic chemicals. However financial profitability of organic tea cultivation has not been proven in the local context.

Therefore the objective of this study was to find $0: 1$ the financial profitability of organic tea cultivation in Sri Lanka in comparison to conventional tea cultivation. The study was conducted using data obtained from Needwood Estate, Haldum rulla. Financial analysis was carried out to measure the profitability using both primary data through interviews with managerial persons of estates and secondary data from TRI publications. Availability of institutional framework to promote the organic tea cultivation was also evaluated.

Result of this analysis implies that the benefit cost ratio of conventional tea is 2.41 while the benefit cost ratio of organic tea is 3.13 . Hence financial profitability of organic tea cultivation is high in compared to conventional tea cultivation. Main reason for the higher profitability of organic tea is due to higher price offered for organic tea. Therefore price sensitivity analysis was undertaken to investigate the impact of price changes. Results show that the profitability of organic tea is not so price sensitive and it changes only with a sharp price drop below $23 \%$ of the current price.

The study found that the absence of institutional framework to promote organic tea is one of the problems for not improving organic tea production it. Sri Lanka. Therefore it is recommended to establish a separate organic product promotion unit within the Ministry of Environment to facilitate promotion of organic production in the colrtry including tea. Ministry of Plantation, Ministry of Agriculture, Ministry of Health and Minist ry of Media should play an active role and work jointly with Ministry of Environment for this. The Ministry of Foreign Affairs and Ministry of Trade should play a major role in explcring international market opportunities for organic tea, which is the key factor for the successful organic tea industry in Sri Lanka. 